Meta

Journal des traducteurs

Translators' Journal

\title{
Translating Woman: Reading the Female through the Male
}

\section{Valerie Henitiuk}

Volume 44, numéro 3, septembre 1999

URI : https://id.erudit.org/iderudit/003045ar

DOI : https://doi.org/10.7202/003045ar

Aller au sommaire du numéro

\section{Éditeur(s)}

Les Presses de l'Université de Montréal

ISSN

0026-0452 (imprimé)

1492-1421 (numérique)

Découvrir la revue

Citer cet article

Henitiuk, V. (1999). Translating Woman: Reading the Female through the Male. Meta, 44(3), 469-484. https://doi.org/10.7202/003045ar

\section{Résumé de l'article}

La critique féministe dit souvent que le sexe de l'auteur et de l'audience peut avoir un impact très profond sur notre compréhension des paradigmes et métaphores littéraires, comme c'est le cas pour le sens et la signification en général. Selon ces critiques, l'expérience de la femme comprend des perceptions et les émotions uniques, et le monde vu par des hommes n'est pas identique à celui vu par des femmes; parce que la différence sexuelle comme construction sociale a des implications importantes sur comment on interprète et comment on est interprété par des autres. Cet article a pour sujet la nature du rapport entre le texte et le lecteur, et l'effet considérable que peut avoir la médiation d'un traducteur. 


\title{
Translating Woman: Reading the Female Through the Male
}

\author{
valerie henitiuk \\ University of Alberta, Edmonton, Canada
}

\begin{abstract}
RÉSUMÉ
La critique féministe dit souvent que le sexe de l'auteur et de l'audience peut avoir un impact très profond sur notre compréhension des paradigmes et métaphores littéraires, comme c'est le cas pour le sens et la signification en général. Selon ces critiques, l'expérience de la femme comprend des perceptions et les émotions uniques, et le monde vu par des hommes n'est pas identique à celui vu par des femmes; parce que la différence sexuelle comme construction sociale a des implications importantes sur comment on interprète et comment on est interprété par des autres. Cet article a pour sujet la nature du rapport entre le texte et le lecteur, et l'effet considérable que peut avoir la médiation d'un traducteur.
\end{abstract}

\begin{abstract}
Feminist literary criticism has argued that our understanding of literary paradigms, metaphors, and meaning in general is profoundly affected by the gender of both author and audience. Critics of this school posit that a woman's experience comprises unique perceptions and emotions, and that women and men do not inhabit an identical world, or at the very least do not view it identically, in that sexual difference as a social construct has implications for how one interprets as well as how one is interpreted. This article discusses the nature of the text/reader transaction, and the effect on the dialogue between a woman writer and her audience of mediation by a male critic and translator.
\end{abstract}

I have the feelings of a woman, but I have only the language of men. - Far from the Madding Crowd

Feminist criticism represents the discovery/recovery of a voice, a unique and uniquely powerful voice

capable of canceling out those other voices.

- The Resisting Reader

Feminist literary criticism has argued that our understanding of literary paradigms, metaphors, and meaning in general is profoundly affected by the gender of both author and audience. Critics from this school posit that a woman's experience comprises unique perceptions and emotions, and that women and men do not inhabit an identical world, or at the very least do not view it identically, in that sexual difference as a social construct has implications for how one interprets as well as how one is interpreted. The present article will discuss the nature of the text/reader transaction, and the effect on the dialogue between a woman writer and her audience of mediation by a male critic and translator.

This discussion draws on three English translations of the acclaimed Kagerô nikki, a diary written by an aristocratic woman of Japan's Heian period (8th-12th century). In the work, the M other of $\mathrm{M}$ ichitsuna ${ }^{1}$ records a period of some twenty 
years, providing an extensive collection of waka poetry detailing her responses to events in her life. The central focus is her unfulfilling marriage to a politically powerful man who, following the quondam custom, was involved with some eight or nine other wives and concubines. For the English-speaking public, the standard version of this work has been Edward Seidensticker's 1964 translation entitled The Gossamer Years. Helen Craig M cCullough re-translated the first of the three books in 1990 as The Gossamer Journal, and Sonja Arntzen has just published The Kagerô Diary, which offers a feminist reading of the entire text. ${ }^{2}$ I $t$ is a common place that works of art can be given almost as many readings as there are readers. Each of the versions mentioned above possesses its own strengths and weaknesses, and together they provide an interesting basis for the consideration of translation as a gendered activity.

Any translation necessarily offers a partial and subjective interpretation of a piece of literature. As critic M arian Ury has noted, "a translator is first of all a reader, and every reader [...] seeks out in [the text] those values most congenial to him" (1977: 183). The perfectly transparent translation is impossible because each translator will give greater or lesser emphasis, subconsciously or otherwise, to different kinds of values, character traits, and impressions. Classical Japanese, generally recognized as one of the least explicit languages ever written, poses particular temptations for exaggeration or, alternatively, excision of certain elements of the texts in the struggle to find meaning in a given passage. Ury goes on to comment that his translation of The Tale of Genji makes it obvious that Seidensticker "responds more to certain values in the text than to others. [...] Yet the mark of a great work of literature is precisely that it appeals to different temperaments in different ways" (1977: 201). The reader who does not have access to the original is a dependent reader who must read the text via the lens of a third person's interpretation, which is inspired by his/ her unique temperament. We will see below how the approach taken by the three translators results in a very different impression of the Kagerô nikki, thus offering essentially altered reading experiences for the English audience.

The fact that history knows the author only as parent to her son underscores the status of woman in her culture, someone whose identity is based primarily on that of the males to whom she is related. While the phrasing "M ichitsuna's M other" conceals her identity, it nonetheless insists on the central fact of her femininity. It is of interest that in Japan, women's literature, far from being marginalized, actually forms the foundations of the literary canon. Authors such as Murasaki Shikibu and Sei Shônagon are among the most celebrated Japanese writers of either gender, and their production has significantly shaped literary development. During the Heian period, rival factions in society competed to prestigiously position accomplished female writers and poets as ladies-in-waiting to well-born women. This situation fostered the talents of many women, who expressed their sensibilities in a variety of literary forms, including poems, letters, and prose narratives such as romances and diaries. Literary salons that formed around an empress, high priestess, or other well-born woman perfected critical faculties as well, as compositions were circulated and their merits discussed by the author's contemporaries. In short, a readership made up by both males and females privileged literature by professional women writers.

Excluded (at least theoretically) by custom and education from learning Chinese, which was employed by men at the court, Japanese women found literary expression in their native Japanese, using the new onna-de (literally, woman's hand) syllabary of 
hiragana. While this script was far from the exclusive preserve of the female sex (men used it in corresponding with their lovers, for example), it was nonetheless highly gendered. Women turned this situation to full advantage, enjoying the freedom of writing in their mother tongue, rather than in a second language ill-adapted to the characteristics of Japanese, and created what strikes today's reader as a very modern style. Lengthy, complex sentences flow in and out of the consciousness of several characters, shifting from first to third person, merging speech, thought, and narrative. Due to the restrictions imposed by a male-dominated society, Heian women wrote primarily within the private rather than the public sphere and were concerned with detailed examinations of inter-personal behaviour rather than sweeping historical or political discussions. Their works emphasize the psychological response of individuals to the subtleties of intimate relationships, and do so with immense beauty and power.

Feminist critics in the West argue that an entire tradition of women's literature has been neglected by male critics. In Japan, although literary fashion and readership have naturally undergone various shifts over the centuries, such tradition has conversely remained well respected and continuous. Nonetheless, the classification of these works as women's literature rather than under the more generic heading of Classical Japanese literature has indeed been neglected, in that elements of importance to a feminist reader have rarely been given their due. To a certain extent, then, these Heian women have been read as men, for the literary canon of Japan can be called pseudo-androcentric insofar as it has been mediated by male critics for the Japanese public, and male translators and critics for the English-speaking public.

What effect does such mediation have on the écriture féminine? Can we trust male readings of these texts to have provided the full story, or have they instead ignored or misread fundamental elements? With a view to shedding light on these very questions, feminists have recently begun offering revisionary re readings of the Genji monogatari, Kagerô nikki, and so on - bringing, in Patrocinio Schweickart's terms, "the nature of the text back into the foreground" (1989: 25). The rationale for focusing on the female authorship of texts has been described as follows: "To see women's writing as our primary subject forces us to make the leap to a new conceptual vantage point and to redefine the nature of the theoretical problem before us" (Showalter, cited in Schweickart 1989: 23). Throughout much of history, criticism the world over has operated solely from a phallocentric vantage point, and thus much of what defines the texts has remained invisible. The objective of feminist criticism is to offer alternate interpretations that allow for a more comprehensive reading of all facets of this literature.

Western interpretations of the Kagerô nikki have until very recently been governed by a mild hostility toward its author, as this comment by Ivan Morris (1985: 255) reveals:

Gossamer Diary, for example, is one long wail of jealousy by a woman in whom the emotion has attained hysterical proportions, and who gives vent in her writing to all the complaints, all the bitterness, all the tension that have accumulated during the long hours of waiting and that social convention prevents her from expressing in any more direct manner.

A similarly patronizing attitude is expressed by Seidensticker: "The insanity of Higekuro's wife in the Tale of Genji and the hysterical jealousy of M ichitsuna's mother 
were perhaps common manifestations of the strain [of a polygynous system] on the mind of the delicate Heian lady" (1964: 19). However, today's readers are far from unanimous that Michitsuna's wrote mainly to complain about the injustice of the system, or to irritate men with her "hysteria" and jealousy. M any critics have focussed on the text's pervasive tone of self-pity, and disparaged its author accordingly. Nonetheless, it should not be forgotten that Japanese critics consider the complaintive tone of M ichitsuna's M other to be partly a conceit of the time, a reflection of the fact that Heian aesthetics did not allow her to express pride and happiness in a straightforward manner. As Arntzen points out: "Given that the literary discourse of her time was designed for the expression of sorrow, even if she should want to convey the joy in her marriage, it might have to be channeled through the discourse of sorrow" (1997: 6).

One of the main motives for creating this text was in fact "to record the poetry she herself had written and that she had received from others, while presenting the contexts that produced it" (Arntzen 1993: 16). Joshua M ostow also takes the position that the author's stature as a poet is absolutely vital to her diary and her life as a whole. He notes that her husband Kaneie may well have married the author precisely for her skill in waka composition, with the expectation that she would both collect their poems to one another and enhance his prestige by making submissions to public poetry competitions (which she did, with marked success). There is no indication that Kaneie objected to his characterization in the diary - a fact that would surprise if their contemporaries were in fact reading the text as a litany of complaint against him and men in general.

A secondary motive is explicitly stated at the very outset of the text: to expose the fallacies contained in the romances popular at the time, and reveal the true situation of a Heian woman married to an influential man through the writing of what could be called an anti-romance. What this indicates is that the Mother of Michitsuna felt a sense of responsibility for passing information about a real woman's life along to her women readers in order to subvert patriarchal fictions about the female experience. Seidensticker does recognize the didactic nature of the Kagerô nikki, calling it "the first attempt in Japanese literature, or in any case the first surviving attempt, to capture on paper, without evasion or idealization, the elements of a real social situation" (1964: 14). However, his overall conception of the work is expressed in these terms: "the author has occasion to record her indignation at successive revelations of rival wives and mistresses [...], and the diary is in a sense her protest against the marriage system of the time and her exposition of the thesis that men are beasts" (1964: 8). This statement is, to say the least, an oversimplification of the message being put forward by M ichitsuna's M other. Those readers who approach her work via an introduction like Seidensticker's are led to read her in a negative, phallocentric way. By concentrating almost exclusively on the jealous woman theme, a great number of critics and translators have aligned themselves along a patriarchal front that distorts the true nature of the text. Their attitude trivializes and marginalizes the work, thus discouraging generations of potential readers from discovering its exquisite prose and poetry, not to mention its strong feminist message.

Arntzen's reading is coloured by an over-riding conception of her protagonist as an intelligent, sensitive woman and poet. Whereas Seidensticker points to the author's "resentment against Kaneie and her venomous rage" as forming "the base 
and many of the high points of the diary" (1964: 9), this feminist translator sees instead the supremacy of the author's poetic talent. Many readers of the original would join her in claiming that the basis and high points of the diary are first, the masterful poems around which the narrative is structured, and second, the depiction of a much broader range of emotions than Seidensticker suggests and translates. McCullough likewise offers a very positive interpretation of the diary, this time as a model of Heian prose (1990: 17):

We know of approximately a dozen female writers whose works survive. The first, and one of the best, was the author of The Gossamer Journal [...] whose treatment of her subject matter - a reflective examination of an unhappy marriage, with many poems and an exhaustive analysis of the nuances of the wife's feelings over the years - not only paved the way for M urasaki Shikibu's psychological probings in The Tale of Genji a generation later, but also produced a narrative of remarkably convincing honesty and grace.

The respect for the authorial skill of Michitsuna's M other expressed here is compromised in Seidensticker's introductory remarks, where the reader is urged to identify him/herself with the male interpretive stance. In comparison, the characterizations offered by these two women critics in their introductions give readers a very different sense of the author, and prepare them to find new and different significations within the text.

Annette Kolodny has argued that there is a fundamental difference between male and female readers, that there is a "necessary gender marking which must constitute any definition of 'peers' in the complex process of unraveling truth or meaning" (cited in Schweickart 1989: 41-42). This is not of course to exclude or denigrate men as readers. Rather, her point is that comprehension of symbolism depends on recognition, and that "female meaning" may well be inaccessible to "male interpretation" unless and until men share similar experiences and frames of reference. Culler is among those who suggest that learning to read as a woman may open up new vistas, awakening readers to the meaning of sexual codes buried in the text that allow them to identify and correct distortions imposed by a male critical vision. Before feminist criticism made inroads into the mainstream it had been true to say that "however inadvertently, [the male reader] is a different kind of reader and, [...] where women are concerned, he is often an inadequate reader" (Kolodny, cited in Schweickart 1989: 460-463). If female authorship is fundamental to the message of a work, one ignores the feminist perspective at the risk of altering the essential nature of the text. As a result, it is of interest to explore the status of what could be called the phallotranslator in his role as an inadequate interpreter of women's writing, given an observable reliance on ingrained phallocentric assumptions. The fact that access to the text is granted through a formula that has the English reader reading "a man translating as a man reading a woman writing as a woman" will have a profound effect on the reading act.

Reading is an activity heavily influenced by what we are taught and the type of texts to which we are exposed: "We read well, and with pleasure, what we already know how to read, and what we know how to read is to a large extent dependent on what we have already read" (Kolodny 1980: 12). Readers learn to interpret texts of a certain type in a particular way owing to social contexts, and so reading must be viewed as a learned social process. Because the male-dominated literary world may 
not have learned how to read the female canon of Heian Japan in its manifold significance, feminist readings offer an opportunity to reveal previously hidden meaning. Of course, not all women read as feminists. As we will see below, McCullough can be considered an immasculated reader, a (fe)male translator who has been taught to read as a man and therefore writes like one.

Reading as a woman has been characterized as a two-fold process. The initial phase comprises feminist readings of male texts, exposing the hostile paradigms by which female characters are presented therein, while the subsequent phase involves discovering and rehabilitating the production of women authors. This article is concerned with the rehabilitation of Japan's female literary heritage, which has been mediated by translators who may not be truly informed or ideal readers. Some have suggested that what is needed is "a community of women readers who are qualified by experience, commitment, and training [...]. The feminist reader takes the part of the woman writer against patriarchal misreadings that trivialize or distort her work" (Schweickart 1989: 29-30). Those holding this position claim that male critics (and/ or immasculated female critics) have been distorting or man-handling the female canon:

In the past, female experience which could not be accommodated by androcentric models was treated as deviant or simply ignored. Observation from an exterior point of view could never be the same as comprehension from within. [...] Both muted and dominant groups generate beliefs or ordering ideas of social reality at the unconscious level, but dominant groups control the forms or structures in which consciousness can be articulated. (Showalter 1988: 346)

Such control is being wrested from the dominant group of phallocentric critics and translators as, by reading the woman in the text, scholars trained in the feminist school seek to reveal the articulation of a different consciousness.

This raises the following question: what is the difference of women's translation? It is clearly essentialist and wrong to claim that one must be biologically female to accurately translate the voice of a woman author. Nonetheless, it would seem only logical to consider an awareness of gender issues essential to a full reading of any text in which the author's life as a woman is a paramount theme. Showalter talks of "the contextual analysis that the anthropologist Clifford Geertz calls 'thick description.' [...] A genuinely 'thick' description of women's writing would insist upon gender and upon a female literary tradition among the multiple strata that make up the force of meaning in a text" (1988: 350). Although Showalter is not speaking of translation per se, the comment certainly applies to a linguistic activity intrinsically concerned with textual analysis and interpretation. After all, what is a translator but a reader-turnedwriter, who not only interprets the text in a personal decoding of its meaning, but is also responsible for transmitting the said interpretation in a reading chain consisting of author $\rightarrow$ translator $\rightarrow$ reader? An informed feminist reader (male or female) of this literature could potentially offer a genuinely "thick" translation that brings out and analyzes layers of the text hitherto downplayed, and (re)presents the woman-astext. As Kolodny points out (1980: 18):

All the feminist is asserting [...] is her own equivalent right to liberate new (and perhaps different) significances from these same text; and at the same time, her right to choose which features of a text she takes as relevant because she is, after all, asking new and 
different questions of it. In the process, she claims neither definitiveness nor structural completeness for her different readings and reading systems, but only their usefulness in recognizing the particular achievements of woman-as-author and their applicability in conscientiously decoding woman-as-sign.

In a report about the work in progress, Arntzen (1993) explains that her own approach was experimental in nature, and that she felt the need to explore a feminist perspective. She had in fact chosen to ask "new and different questions" from those considered relevant by her predecessors.

The question of how we read is as important as what we read. Because the $\mathrm{H}$ eian women's texts are canonical, it cannot be denied that they are read. However, the manner in which they have been read is ineluctably influenced by the fact that criticism in Japan has been predominantly male, and that most English-speaking readers and researchers have had access to these works solely through translators unversed in gender issues. Schweickart states that today's readers must compensate for the way in which "the experiences and perspectives of women have been systematically and fallaciously assimilated into literature" (1989: 24). In the past, little account has been taken of a woman's point of view, commonly dismissed or misrepresented according to a self-serving male interpretation.

When the Kagerô nikki is mediated by translators insensitive to the female voice, it is likely that both text and readers suffer a significant loss. Arntzen (1993) relates her discovery of just what had been lost in translation.

Reading the original text, I was not prepared for its exquisite beauty. It was not that the content was so different from Seidensticker's translation, but the mode of expression, the language was so different. (Arntzen 1993: 17)

She goes on to describe finding echoes of this "mode of expression" in Virginia Woolf and Canada's Daphne Marlatt, writers known for consciously seeking means to express a woman's voice. Many other critics have pointed out the striking resemblance between the innovative narrative styles employed by Woolf and Heian woman writers. $^{3}$ O ne is tempted to ask whether Seidensticker and others are guilty of de-sexing or even immasculating the M other of Michitsuna in their failure to transmit essential female-coded elements of her literary style.

The translation process involves domestication of a text. While translators by definition deal with a foreign text on levels of language, culture, and time, the male translator of a woman's text may well encounter a foreignness comprised of sexual difference that he ends up compounding. The language of the male translator is superimposed on the woman's narrative, creating inevitable gender-bending distortions. The coding of language as either masculine or feminine has lately been a major theme in discussions concerning the literature of the Western world:

The central issue in much recent women's writing in France is to find and use an appropriate female language. Language is the place to begin: a prise de conscience must be followed by a prise de la parole... In this view, the very forms of the dominant mode of discourse show the mark of the dominant masculine ideology. Hence, when a woman writes or speaks herself into existence, she is forced to speak in something like a foreign tongue, a language with which she may be uncomfortable. (Carolyn Burke, cited in Showalter 1988: 339) 
The situation of Japanese women writers in the tenth and eleventh centuries was unique. They were developing the native prose tradition, generally recognized as female, while their male counterparts wrote primarily in the foreign tongue of $\mathrm{Chi}$ nese. In a way, the last sentence quoted above suggests in reverse what has happened with English translations of Heian onna-de texts: males have been attempting to understand a (female) foreign tongue, unaware of all they are missing and misreading.

Phallocentric translators may succeed in only superficially translating the woman-as-text, unaware of other, deeper levels of significance. Showalter comments that "there is some ethnographic evidence that in certain cultures women have evolved a private form of communication out of their need to resist the silence imposed upon them in public life" (1988: 340). It is interesting to speculate whether women readers, by virtue of shared experiences as females within similarly oppressive patriarchal systems, have the innate ability to comprehend an underlying text that remains inaccessible to men. Showalter goes on to cite Gilbert and Gubar's notion of the "palimpsest," where a muted story has been concealed beneath the dominant one (1988: 350):

'In the purest feminist literary criticism we are [...] presented with a radical alteration of our vision, a demand that we see meaning in what has previously been empty space. The orthodox plot recedes, and another plot, hitherto submerged in the anonymity of the background, stands out in bold relief like a thumbprint.' Miller too sees 'another text' in women's fiction, 'more or less muted from novel to novel' but 'always there to be read.'

Reading the submerged text requires an active choice to do so, as well as possession of the appropriate tools and the ability to ask the right questions that will bring it into the foreground. Translations produced by male readers may well silence parts of a woman author's message by being simply oblivious to the significance of, for example, metaphors of sexual power relationships. Far from being able to read the alternate plots/meanings, phallo-translators may not even want to see that they exist. They would be "resisting readers," to apply Judith Fetterley's term (1978) in a new context - resistant to subversive meanings and characterizations in texts that may threaten the patriarchy and its view of the world. Where a muted female story which may or may not involve subversion, is essential to the text, such selective translation would constitute gross misrepresentation. Naturally, the understanding available to a woman reader forced to read through the male would be limited in some way.

In the West, women's writing has been variously described as fluid, vague, and lacking what Anthony Burgess termed "a strong male thrust." Feminist critics have sought to portray this difference as an advantage by defining a distinctively feminine sentence. In her historical overview of women's autobiography, Jelinek claims to recognize a recurring pattern, in that "women often depict a multidimensional, fragmented self-image" and make use of a style that is "episodic and anecdotal, nonchronological and disjunctive" (1986: xiii). Throughout her translation, Arntzen shows a willingness to leave matters ambiguous and retain the original's disjunctive narration, which both of the other translators examined here resist. Anyone knowing this text only via Seidensticker and M cCullough would be, for the most part, unaware that the "text is disjunctive in the sense that the narrative is constantly being inter- 
rupted by poems, the quotations of voices of others, and the intrusion of the author's own thoughts as bits of interior conversation" (Arntzen 1997: xi). The Mother of Michitsuna writes with amazing suppleness, providing a model for later authors. Richard Okada notes "a strong predilection for linguistic experimentation and play" in Heian women's literature, which can be demonstrated to be largely absent from most English translations of these works (1991: 32).

O verall differences between male and female writing have been characterized as follows: "the dichotomy is between masculine attempts to pin things down and feminine emotion and elusiveness" (Brownstein 1994: 278). ${ }^{4}$ M any works of feminist criticism have posited that a female aesthetic, non-linear in nature, exists and may be represented through tools such as a fragmented syntax and a disparate narrative voice. Still and Worton comment that although "breaking forms may be a courageous masculine act of aggression, [...] degrees of formlessness are usually coded feminine" (1993: 23). Both Seidensticker and McCullough avoid reproducing these elements, likely because of the difficulties of producing readable English out of such "formlessness," while Arntzen chooses to experiment within a so-called feminine style. Indeed, a perception that a distinctive woman's voice has been muffled by Seidensticker is the inspiration for her book:

I realized then [upon reading the original] that while The Gossamer Years, Edward Seidensticker's deft and clear translation of Kagerô nikki, conveyed the content of the text, it gave little sense of the style, and perhaps the style was crucial. In the style was the material of interest to those engaging in questions of the construction of the female self in literature, the issue of truth and fiction in autobiography, and the distinctiveness of woman's voice and language in literature. A new translation seemed essential. (Arntzen 1997: $\mathrm{x}$ )

In embracing the distinctive language of her author, this translator breaks with others who have forced the prose written by M ichitsuna's M other into the mold of a (masculine) logical narrative flow, whereby conjunctive phrases are added, ellipses filled out, and tense unified. While cognizant that fractured sentence structure will pose a challenge to readers unused to this kind of writing, the feminist translator takes faithful representation of style as well as content to be the guiding rule. In addition, it is perhaps significant that there is a female oral tradition among women at work here, as these texts were frequently read aloud by women to one another during the Heian period. Arntzen recognizes that her text "has become a translation [...] that with its long, run-on sentences looks a little formidable on the page but makes sense when read aloud" (1997: xi). What this suggests is that use of a "female" sentence structure ushers readers into a feminine literary sphere isolated from the world of men where they experience a life as recounted by and to women or Woman.

The exterior world of politics and public life plays almost no part in the Kagerô nikki. Writers such as Jane Austen have often been criticized for producing inwardlooking "drawing room fiction," and similar charges are laid against Michitsuna's M other: "... shut off with her problem, the author was but dimly aware of what was going on outside. [...] Hers, then, was a dark and narrow sort of realism. For the most part she was not able to see beyond herself" (Seidensticker 1964: 16). The text makes it clear, however, that she set out to write neither public history nor political memoirs; she was writing about her life and self, and this personal account of an aristo- 
cratic woman's existence must betaken for what it is. By her use of the hiragana script and native language, rather than kambun, or Sino-Japanese, M ichitsuna's Mother consciously rejects the tradition of public writing established by her male contemporaries, which was not an option for women of her time anyway. As Arntzen states in her introduction, Japanese prose "was very new and was appropriated by women who, being at the margins, had the freedom of irrelevance" (1997: 42). The potential for experimenting and developing a native prose style was ironically the preserve of the relatively disempowered.

An example from the first section of the Kagerô nikki illustrates this point. McCullough informs her readers that Book One, "a self-contained entity with a definite beginning and ending, is a poem-studded retrospective account of the first fifteen years of the marriage, a period during which the narrator's primary emotions are anxiety, jealousy, resentment, and sadness" (1990: 73). These pages set the stage for the emotional journey undertaken by M ichitsuna's M other. Let us examine how the three translators handle the well-known opening paragraph, which has been described as "one of the vaguest and yet most pathetically effective in the whole diary" (Seidensticker 1964: 28).

Taking the first sentence in isolation, we see that its sense does not prove especially problematic, as all three versions offer essentially the same reading, with only relatively minor variations in wording:

Original: Kakuarishi toki sugite, yo o naka ni ito mono wa kanaku, tonimokaku ni motsuka de, yo ni furu hito arikeri. (p. 125)

Seidensticker: These times have passed, and there was one who drifted uncertainly through them, scarcely knowing where she was. (p. 33)

McCullough: There was once a woman who led a forlorn, uncertain life, the old days gone forever and her present status neither one thing nor the other. (p. 102)

Arntzen: $\quad$ Thus the time has passed and there is one in the world who has lived such a vain existence, catching on to neither this nor that. (p. 57)

While the meaning appears straightforward, the troublesome issue of verb tense already announces itself. The last version stands alone in opting to convey a hint of the indeterminate tense usage of the original. Of course, finding English equivalents for Classical Japanese verb tenses is rarely obvious. Okada, citing Japanese grammarians, describes keri (the end-position verbal modal-aspectual suffix used throughout the diary) as bringing "the past into the present moment [... given that] when keri is used, the past is conceived of in some manner as existing at the present moment" (1991: 38). The pattern typically followed by M ichitsuna's M other is first to establish the frame of narration as the past, and then to switch to a combination of present and suspended verbal tense forms that give the sense of events unfolding in the present. As a result, the temporal distinction between the narrating moment and the events being narrated is much less clear-cut than either Seidensticker's or McCullough's translation would indicate.

Arntzen's decision to create a more or less tenseless narrative in the diary's opening line is significant to her entire version, a fact which becomes clear as the reader moves on to the fluid, almost labyrinthine second sentence. M ichitsuna's M other repeatedly alters her narrative structure to vary between past- and presenttense verbs as well as first- and third-person subjects. The following sentence, ren- 
dered below by Arntzen, is thus highly characteristic of her style. (The Japanese original is provided in the appendix.)

As for her appearance, she can hardly be compared to others, and her intelligence- to say she has some is as good as saying she has none at all- so it is only natural that she has come to such a useless state she thinks again and again; it is just that in the course of living, lying down, getting up, dawn to dusk, when she looks at the odds and ends of the old tales- of which there are so many, they are just so much fantasy- that she thinks perhaps if she were to make a record of a life like her own, being really nobody, it might actually be novel, and could even serve to answer, should anyone ask, what is it like, the life of a woman married to a highly placed man, yet the events of the months and years gone by are vague; places where I have just left it at that are indeed many. (1997: 57)

The narrative flow is indicative of the stream-of-consciousness favoured by Arntzen in her attempt to capture the author's style as accurately as possible. The effect is highly reminiscent of modern feminist writing and Jennifer Waelti-Waters' description of M onique Wittig's radical prose: "Gone are the single narrator, unity of tone, precision in time and space [...]. Gone also are all the usual kinds of linear, logical structure and binary oppositions attributed to rational 'apollonic' thought" (cited in Still and Worton 1993: 25).

In contrast, the other two versions are revealed to be brisker and far more quotidian. First, the Seidensticker translation (1964: 33):

It was perhaps natural that such should be her fate. She was less handsome than most, and not remarkably gifted. Yet, as the days went by in monotonous succession, she had occasion to look at the old romances, and found them masses of the rankest fabrication. Perhaps, she said to herself, even the story of her own dreary life, set down in a journal, might be of interest; and it might also answer a question: had that life been one befitting a well-born lady? But they must all be recounted, events of long ago, events of but yesterday. She was by no means certain that she could bring them to order.

Here the reader receives a very different impression of the text, given that the translator has tidied up the overall structure, establishing clear connections and breaks between the multiple clauses, unifying the tense, and stabilizing the subject. Seidensticker's introduction discusses why revision of a previously published version (1959) was felt necessary: "I had in those days an exuberantly free notion of what a translation was, and did not mind helping my authoress when on occasion her ability to express herself seemed to falter" (1964: 25). To judge from this 1964 translation, however, Seidensticker is still "helping" M ichitsuna's M other express herself, unwilling to let the syntax stand as she wrote it, and deleting anything he deems superfluous.

Turning to McCullough, we see that while she elaborates a little more, her syntactical strategy is similar:

Telling herself that it was natural for a man to attach no value to someone who was less attractive than others and not very bright, she merely went to bed and got up day after day. But then it occurred to her, as she leafed through the many current tales of the past, that such stories were only conventional tissues of fabrications, and that people might welcome the novelty of a journal written by an ordinary woman. If there were those who wondered what it was like to be married to a man who moved in the very highest 
circles, she might invite them to find an answer here. Her memory was not good, either for the distant past or for more recent events, and she realized in the end that she had written many things it might have been better to omit. (1990: 102-103)

The definitive source texts, including Shôgakkan, punctuate all the above as one sentence, a fact reflected in only the most recent translation. In an effort to make this admittedly convoluted sentence more readable, McCullough divides it into five distinct parts, and Seidensticker into seven. It should be borne in mind that the original has none of the choppiness inevitably created by such use of a series of short sentences, but instead employs a loose, non-linear flow and a relaxed, if somewhat incoherent, phrasing. In fact, Bowring argues that a characteristic feature of Heian women's writing is "a constant undermining of narrative coherence" (1987: 55). The original gives its reader a sense of eavesdropping on the author's thought process, witnessing or even participating in the creation of the text, rather than simply serving as a receiver of ready-made and readily-comprehensible sentences. One way of looking at it is that, instead of falling "plump to the ground-dead," this prose "explodes and gives birth to all kinds of other ideas [and] has the secret to perpetual life." $M$ ichitsuna's M other seems to have instinctively understood what Woolf was to explain some thousand years later, that writing does not consist of "sentences laid end to end, but of sentences built, if an image helps, into arcades or domes" (1995: 73). The style of the Japanese prose, which Arntzen alone has attempted to render, allows the reader to watch as these structures take shape or participate in constructing them. (Whether this attempt is felicitous or merely creates an overly avant-garde text that is inaccessible and thus elitist is open to debate.)

McCullough offers a middle ground between the other versions, and thus it may be most instructive to concentrate primarily on a comparison of the other translations as comprising two extremes. Reviewers have frequently commented on Seidensticker's "habit of brevity" (Ury 1977: 197) and "encapsulating tendency" (Cranston 1978: 12) in his other translations and, taking the two (original) sentences together, we see that it takes him a mere 129 words to render what in McCullough takes 169 words, and in Arntzen, 187 (for a difference of some 30 and 50\%, respectively). While no one would suggest that word count is in itself an adequate basis for judging translation quality, it does reveal a significant trend on the part of Seidensticker (and to a lesser degree M cCullough) to omit or suppress much of the author's narrative flow. Cranston underscores elsewhere that Seidensticker "tends toward condensation and reductionism," that his style "tends to be spare and rapid," and that his "tone can seem offhand and almost flippant at times" (1978: 6, 14 and 24, respectively). All of these tendencies are present throughout his Gossamer Years, and beg the question of whether the reader of the translation is being permitted to respond to the original author or merely a cross-dressing Seidensticker.

Seidensticker is often impatient with his author, whose thoughts can meander in a seemingly aimless way. H owever, as Arntzen rightly points out, such meandering is a defining characteristic of her style: "The sentences follow the flow of the author's mind creating something analogous to a 'stream of consciousness' effect" (1997: 47). What a reader schooled in feminist theory may view as refreshingly modern and subtle appears to be anathema to someone of Seidensticker's temperament. Ury (1977: 198-200) has said that his 
taste is for brightness; he likes bright images and strongly realized scenes. [...] Conventional expressions are deleted. Redundancies are also eliminated. Seidensticker has always been wary of these. [...] Perhaps it is a matter not so much of eliminating redundancy as of shaping the narrative itself to a more vigorous taste. ${ }^{6}$

Again, "bright" and "vigorous" are hardly the adjectives that leap to mind when reading the languorous prose developed by $\mathrm{H}$ eian women. As a result, any translation that can be so described becomes suspect.

M ichitsuna's M other thus undergoes a transformation in Seidensticker's hands. In her "Imaginary Kingdom" article, Ury discusses how Arthur Waley managed to capture Murasaki Shikibu's subjective narrative style in his translation of The Tale of Genji: "A frequent device is interior monologue: a sufferer weighs this alternative and that, a germ of suspicion forms, is reasoned away, returns... No quotation marks are used, for the thoughts float through the mind not quite fully formed" (1976: 280). She contrasts this fluidity with Seidensticker's translation of the same masterpiece, written with far greater terseness. The notion of imperfectly formed threads of thought is significant, since it is a fundamental characteristic of Heian women's writing. In another article, Ury points out that some readers of the original Genji monogatari are disappointed at Seidensticker's preference for excising and simplifying: "There are many readers for whom the hesitations, regrets, repetitions and partial contradictions in the thought and behavior of the characters are of the very essence of this novel" (1977: 200). It is generally believed that Murasaki Shikibu must have read and been influenced by Michitsuna's M other, and one indication of this debt is their mutual privileging of these "hesitations" and "partial contradictions."

A glance at the overall look of the translations immediately reveals two things: that the earliest differs from the others in incorporating the short poems directly into the prose, and that the most recent lacks the dated entries present in the other two. As Still and Worton note, twentieth-century experimentation with the placing of words on the page has proven that texts can no longer be considered transparent vehicles for communication. Setting the poems off from the prose not only adds visual punch, but also highlights their central role. One senses that Seidensticker saw the poetry as yet another disjunctive flaw interrupting the narrative, and thus something to be smoothed over wherever possible. As we showed earlier, however, the author's role of poet is fundamental to her work: downplay the role of verse and the result is no longer the work as Michitsuna's M other conceived it.

As for the second point, both Seidensticker and McCullough insert historical references not present in the original, ostensibly to make the Kagerô nikki read more like a diary in the Western sense of the word. It has, however, been noted that in Heian texts:

the women never situate their writings in a concrete, historical context. There are few dates, few names, no references to political realities. It is as if the women have consciously cut away that part of the world over which they have no power, to concentrate entirely on private fears and sorrows. (Bowring 1987: 55)

The translators' forcing of the text into a foreign mold, then, causes ineluctable damage, making concrete and explicit what the author intentionally chose to leave vague. It seems to indicate a patriarchal preference for history and for valuing the personal in relation to the public despite a feminine discourse concerned solely with 
relationships and a self in need of correction and improvement. Julia Kristeva has asserted that "every text is under the jurisdiction of other, and often alien or hostile, discourses which impose upon it a context which it seeks to transform" (cited in Still and Worton 1993: 4). Here we clearly have an alien discourse imposed by translators on the female text written by Michitsuna's M other.

In reference to the process of decoding the inherent foreignness of language as used by men and women, Barbara Johnson says that "what Bloom demonstrates, perhaps without knowing it, is that if reading is the gendered activity he paints it as, the reading process is less a love story than a story of failed translation" (1989: 51). Bearing in mind that readers do not simply receive the meanings of a text but cooperate to some degree in constructing them, both textual production and reception can be coded as either masculine or feminine. In responding to a text, readers are in fact trying to "translate" it into a meaning they can understand, and sexual difference may frequently and severely distort genuine communication. It has been argued that the context of production is an intrinsic part of the text that encompasses the gender of both author and audience. If so, the gender of the translator has just as significant and inescapable an impact on reader response. If meaning were a stable entity inherent exclusively in the text, the translator would have no effect on that meaning. On the other hand, if Stanley Fish is correct in holding that meaning is completely subjective and found solely in an individual reader's act of processing the text, all translations would be equally valid. Common sense leads us to believe that the answer lies somewhere along a continuum between these two points, and that the mediation of translation can thus have far-reaching implications for the act of reading a given text.

Meaning is, at least partially, a function of interpretative strategies and conventions internalized by a reader in his/her role as a member of an interpretive community. The echo of a society halfway around the world and thousand years in the past, $\mathrm{H}$ eian literature is replete with indeterminacy for readers in late twentieth-century North America. It is impossible for us to duplicate the reader-response conditions of the Mother of Michitsuna's contemporaries, nor can we ever know her authorial intentions. This does not mean that we should not continually seek to discover the true meaning of the text, as opposed to putting forth interpretations overly influenced by the values of our community, whether phallocentric or feminist.

What we in the West normally understand by the term diary only partially coincides with the Kagerô nikki, which "exhibits some diary-like features but shifts between first- and third-person narration and suppresses material irrelevant to a clearly defined central theme" (M cCullough 1990: 7). Any translation that attempts to hide these vital differences in the nature of the text appears somewhat less than competent at best, and dishonest at worst. Certainly, any text so distant from us in time and geography will present many passages that are difficult to understand. The wording is frequently unclear, and conflicting interpretations are legion. As Seidensticker himself comments (1964: 27), however:

the variations possible because of obscurities in the text are less difficult to explain than variations possible because every translator has his own idea of what he is up to. Unless a translation is hopelessly inaccurate [...] it cannot be judged apart from the translator's aims. 
The goal of this article has been to demonstrate that two of the Kagerô nikki translations discussed, while far from "hopelessly inaccurate" in terms of content, do present a potentially inaccurate image of M ichitsuna's M other and her writing because their aims conflict with hers. ${ }^{7}$ Given that translation is arguably the most active form of reading and interpretation, it inevitably affects the author-reader relationship. We have seen that where the production of Heian women authors is concerned, gender issues must form an integral part of the analysis by both critics and translators. While these women did enjoy a privileged position as acknowledged authors and poets, they were nevertheless writing themselves out of the oppressive confines of patriarchal space. Any translator who does not recognize this fact, and who neglects to give the concept of the author-as-woman the attention it deserves, cannot avoid doing violence to a text where this concept is inseparable from the text itself.

\section{NOTES}

1. M ichitsuna is the author's son by her husband, Kaneie. During the Heian period, it was considered improper to record the names of women, other than empresses, imperial consorts, and so on. Female authors of the time are now remembered by the names and/or titles of their male relations, as are, for example, Takasue's Daughter, author of The Floating Bridge of D reams, and Sei Shônagon, author of The Pillow Book (Sei = Sino-Japanese reading of family name "Kiyowara;" Shônagon = her father's title). This rule also holds true for Murasaki Shikibu, who gave us The Tale of Genji; while "Murasaki" is borrowed from one of her characters, "Shikibu" was a title her father held.

2. There also exist a number of modern Japanese translations of H eian literature, including versions by such famous writers as Yosano Akiko, Tanizaki Jun'ichiro and Enchi Fumiko that have been much loved by the reading public. It is beyond the scope of this paper to explore the handling of the female voice by male and female Japanese translators (Tanizaki being the sole man among the three).

3. For example: "It so happens that Woolf's language, especially after M rs. Dalloway (1925) and To The Lighthouse (1927), has features uncannily like those of Lady M urasaki's as I read the two women writers from two vastly different translations and times. [...] The experiment with stream-of-consciousness is one such attempt: depersonalizing of the narrative voice, disembodying of characters, loosening of the point of view, immersing of the spatial structure of the novel in the flow of time are all similar endeavours. One idly wonders what might have happened had Woolf learned to read Japanese, or, better still, had she translated The Tale of Genji!" (M iyoshi 1979: 301).

4. To illustrate this point, Brownstein (1994: 86) cites Jane Austen's Emma: "[Robert Martin's letter] is not the style of a woman; no, certainly, it is too strong and concise; not diffuse enough for a woman."

5. As Virginia Woolf described masculine and feminine, or androgynous, sentences (Woolf 1995: 97).

6. On page 199, Ury also cites V.S. Pritchett as claiming that Seidensticker has a penchant for the "heavily jaunty word," which occasionally provides an oddly jarring effect.

7. As an aside, we might note that Seidensticker devotes a large part of his introduction of a work by and about a woman to discussing the life and habits of "the Heian gentleman."

\section{REFERENCES}

Ar nt zen, Sonja (1993): "Translating Difference in the Kagerô nikki", TheJapan Foundation N ewsletter, 21 (3), pp. 16-19.

- - (tr.) (1997): The Kagerô Diary [Kagerô nikki], Ann Arbor, University of Michigan Press.

Bowring, Richard (1987): "The Female Hand in Heian Japan: A First Reading", The Female Autograph: Theory and Practice of Autobiography from the Tenth Century to the Twentieth Century, St ant on, Donna C. (Ed.), Chicago, University of Chicago Press.

Brownst ein, Rachel (1994): Becoming a Heroine: Reading about Women in Novels, New York, Columbia University Press.

Cr anst on, Edwin (1978): "The Seidensticker Genji" [ review article], Journal of Japanese Studies, 4 (1), pp. 1-25. 
Cul l er , Jonathon (1983): “Reading as a Woman”, On Deconstruction: Theory and Criticism after Structuralism, London, Routledge.

Fet t er I ey, Judith (1978): The Resisting Reader, Bloomington, Indiana University Press.

Fiel d, Norma (1987): The Splendor of Longing in The Tale of Genji, Princeton, Princeton University Press.

Jel in ek, Estelle C. (1986): The Tradition of Women's Autobiography: From Antiquity to the Present, Boston, Twayne Publishers.

Johnson, Barbara (1989): "Gender Theory and the Yale School", Speaking of Gender, Sh owal t er , Elaine (Ed.), New York, Routledge.

Kol odny, Annette (1980): "Dancing Through the Minefield: Some Observations on the Theory, Practice and Politics of a Feminist Literary Criticism", Feminist Studies, 6 (1), pp. 1-25.

M at su mur a, Sei'ichi, Kimura M asanor i and Imuta Tsun eh isa (Eds.) (1973): Tosa nikki. Kagerô nikki, vol. 9 of Nihon koten bungaku zenshû, Tokyo, Shôgakkan.

M cCull ough, Helen Craig (tr.) (1990): "The Gossamer Journal [Kagerô nikki]", Classical Japanese Prose: An Anthology, Stanford, Stanford University Press.

M il l er, Marilyn Jeanne (1985): The Poetics of Nikki Bungaku: A Comparison of the Traditions, Conventions, and Structures of Heian Japan's Literary Diaries with Western Autobiographical Writings, New York, Garland Publishing, Inc.

M iyosh i, M asao (1979): "Translation as Interpretation" [review of Seidensticker's translation of The Tale of Genji], Journal of Asian Studies, 38 (2), pp. 299-302.

M or r is, Ivan (1985): The World of the Shining Prince: Court Life in Ancient Japan, New York, Penguin.

M ost ow, Joshua S. (1992) "The Amorous Statesman and the Poetess: The Politics of Autobiography and the Kagerô Nikki", Japan Forum, 4 (2), pp. 305-315.

0 kada, Richard (1991): Figures of Resistance: Language, Poetry, and Narrating in the Tale of Genji and Other Mid-Heian Texts, Durham, Duke University Press.

Richie, Donald (1997): "The Asian Bookshelf: Another Look at the 'Golden Era' of 'Genji'" [review of Arntzen's The Kagerô Diary], The Japan Times, November 16.

Schw eickart , Patrocinio P. (1989): "Reading Ourselves: Toward a Feminist Theory of Reading", Speaking of Gender, Sh owal t er, Elaine (Ed.), New York, Routledge.

Seidenst icker , Edward (tr.) (1964): The Gossamer Years [Kagerô nikki], Tokyo, Charles E. Tuttle Company.

Sh owal ter , Elaine (1988): "Feminist Criticism in the Wilderness", M odern Criticism and Theory: A Reader, David Lodge (Ed.), London, Longman.

St il I, Judith and M ichael Wort on (Eds.) (1993): Textuality and Sexuality: Reading Theories and Practices, Manchester, M anchester University Press.

U ry, Marian (1976): "The Imaginary Kingdom and the Translator's Art: Notes on Re-reading Waley's Genji", Journal of Japanese Studies, 2 (2), pp. 267-294.

- - (1977): "The Complete Genji" [review of Seidensticker's translation of The Tale of Genji], Harvard Journal of Asiatic Studies, 37 (1), pp. 183-201.

Wal ey, Arthur (1967): “The Gossamer Years", Journal of Asian Studies, pp. 344-345.

Woolf, Virginia (1995): A Room of One's Own, Cambridge, Cambridge University Press.

\section{APPENDIX}

In the original, the second sentence of the Kagerô nikki reads as follows (p. 125):

かたちとても人にも似ず、心だましひもあるにもあらで、からものの要にもあら であるも、ことわりと思ひつつ、ただ卧し起き明かし暮らすままに、世の中にお ほかる古物語のはしなどを見れば、世におほかるそらごとだにあり、人にもあら ぬ身の上まで書き日記して、めづらしきさまにもありなむ、天下の人の品高きや と問はむためしにもせよかし、とおぼゆるも、過ぎにし年月ごろのこともおぼつ かなかりければ、さてもありぬべきことなむおほかりける。 